\author{
Malgorzata Marzec \\ Jagiellonian University \\ e-mail: malgorzata.marzec@uj.edu.pl \\ ORCID: 0000-0002-6833-554X
}

\author{
Agnieszka Szczudlińska-Kanoś \\ Jagiellonian University \\ e-mail: agnieszka.szczudlinska-kanos@uj.edu.pl \\ ORCID: 0000-0002-7382-4858
}

\title{
LEGITIMIZATION OF PENSION INSTITUTIONS. NEED OR NECESSITY?
}

\section{LEGITYMIZACJA SYSTEMU EMERYTALNEGO. POTRZEBA CZY KONIECZNOŚĆ?}

DOI: $10.15611 /$ pn.2019.9.15

JEL Classification: G230, H550, E690

\begin{abstract}
Summary: The pension system in its functioning and activity should be legitimized as an actual condition in performing specific tasks in accordance with the general requirements and expectations attributed to the pension system. In the case of institutions of the pension system, legitimacy should concern both the organization of the system itself ensuring the implementation of basic tasks, e.g. ensuring system security, guaranteeing the solvency of certain benefits, etc., as well as organizations at the level of individual institutions (public and private). The aim of the article is to analyze the issue of legitimizing the pension system from the point of view of institutions operating in the pension system. The article is teoretical and presents a model enabling understanding of the significant problem of legitimization against the background of functioning pension institutions. The study presents the adaptation of the conceptual (semantic) apparatus to the analysis of the legitimacy of the pension system.
\end{abstract}

Keywords: legitimization, pension system, social responsibility.

Streszczenie: System emerytalny w swoim funkcjonowaniu i działalności powinien cechować się legitymizacją jako faktycznym warunkiem w wykonywaniu określonych zadań zgodnych z ogólnymi wymogami i oczekiwaniami przypisywanymi systemowi emerytalnemu. W przypadku instytucji systemu emerytalnego, legitymizacja powinna dotyczyć zarówno samej organizacji systemu zapewniającego realizację podstawowych zadań, np. zapewnienie bezpieczeństwa działania systemu, gwarantowanie wypłacalności określonych świadczeń itp., jak też organizacji na poziomie poszczególnych instytucji (publicznych i prywatnych). Celem artykułu jest analiza zagadnienia legitymizacji systemu emerytalnego z punktu widzenia instytucji działających w systemie emerytalnym. Artykuł ma charakter teoretyczny 
i przedstawia model umożliwiający zrozumienie istotny problemu legitymizacji na tle funkcjonujących instytucji emerytalnych. Opracowanie przedstawia przystosowanie aparatu pojęciowego (znaczeniowego) do analizy legitymizacji systemu emerytalnego.

Słowa kluczowe: legitymizacja, system emerytalny, społeczna odpowiedzialność.

\section{Introduction}

The pension system which has been functioning in Poland since 1999 has been subject to many reforms that have changed the pension system rules and the activities of individual institutions within the system a number of times. Legitimisation is analysed as the idea which states that the actions of individuals (system, entities) are desirable by the environment and in accordance with social norms and values. In this study, legitimization is understood as "evoking the belief that structures, procedures, activities, decisions, policy directions, officials, and leaders have the properties of rightness, adequateness, and moral value, and that they should be accepted due to these values" (Dahl, 1963, p. 19, compare: Kubin, 2014, p. 33). Legitimization is linked with recognition and feeling that "people identify with institutions and processes that affect their lives - they consider them as right and perceive them as their own" (Banchoff, 1999, p. 184). In its operation and activity, the pension system should be characterized by legitimization as an actual condition in performing specific tasks in accordance with the general requirements and expectations attributed to this system.

In the case of the pension system, legitimization should apply to the organisation of the system itself, ensuring the implementation of basic tasks, e.g. ensuring the system's operation security, guaranteeing payment of certain benefits, accumulating appropriate capital, etc., as well as the organisation at the level of individual institutions operating in the pension system (both public and private). The authors take the position that legitimization should be based on the fact that a system or institution should be perceived as responsible towards society. In the study, the legitimization of the pension system is presented from three points of view, i.e. as the adjustment of the environmental dimensions of the operation of pension institutions, the justification for the operation of a specific institution socially (for the benefit of society), and the assumption that the system operates in accordance with the norms, values, and beliefs. The indicated planes set the framework for the article analysis.

The article is divided into three parts. First, the theory of legitimization is presented, and the determinants impacting legitimization are described. The analysis is based on the subject literature review. Next, the pension system is characterised from the point of view of the principles of the functioning and implementation of tasks for society. A description of the institutions and procedures operating in the pension system has been deliberately made taking into account the purpose of the article. The study attempts to present the impact of the theory of legitimization of the pension system against the background of the recent reforms of the Polish pension system. 
The purpose of this article is to analyse the issue of legitimizing the pension system from the point of view of the institutions operating within it. The article is of a theoretical nature and presents a model that enables understanding the essence of the problem of legitimization against the background of the functioning pension institutions and the implemented reforms. In the literature one can find studies on the legitimization of the political system or the institutions (bodies) of power, however there is a lack of studies on the legitimization of the pension system. The article attempts to fill the indicated research gap. The authors have aimed to adapt the conceptual and semantic apparatus to the analysis of the pension system's legitimization. The thesis, the truth of which the authors are trying to prove owing to the considerations made is as follows: the legitimization of the pension system is an essential element of this system's functioning. The text should fill in the gap in the theoretical considerations on the legitimization of the functioning of the pension system, paying attention to the social support and acceptance of mechanisms determining the system described.

\section{Adaptation of the term to the conditions of the pension system}

The issue of legitimacy is interdisciplinary and has been adressed by many sciences, including sociology, theory of state and law, political science, law, political history, and social psychology. The concept of legitimization can already be found in antiquity. The term 'legitimization' comes from the Latin word legitimus, which means lawful, or referring to medieval Latin it should be combined with the word legitim (Winczorek, 1985; Kosturbiec, 2001). In the Polish Language Dictionary this term is explained as "giving legal force to something" or "recognizing a given political system as the most suitable for a given type of society" and is compared with the legitimacy of power (Stownik Języka Polskiego PWN, n. d.). It seems important to separate the concept of legitimacy understood as a certain state of the system (usually political) from legitimization which is connected with the process that leads to this state. In the subject literature, legitimization is used to substitute the concepts of legitimacy, sanctioning, rightfulness, and validity.

Over time, there have been changes in the approach to analysing the problem of legitimization. Initially, legitimacy was treated in traditional doctrine, with reference to different criteria of legitimacy. Then the liberal theory of the legitimacy of power developed which recognised power as legitimate only in the case of one that could ensure broad participation of citizens in governing and have with their support (Lipset, 1960; cf. Sokół, 1997). Another concept is linked with the so-called "conviction". A legitimate system only occurs when at least a part of society ("active minority") considers it to be "binding", while other groups are unable to provide an alternative to the "promoted" model of action (Kosturbiec, 2001, p. 3).

Legitimization is a complex phenomenon with of a multidimensional nature (Beetham, 1993, p. 15; compare Żyromski, 2012, p. 19). Not only the method of 
gaining power is important, but also the methods of using this power. The question that should be asked is to what extent authority is legitimized, what caused it to obtain legitimacy and how important is it? An approximation of this problem should become the basis for analysing the legitimacy of the pension system. The legitimization process should be considered at three closely related levels, i.e. principles, justification, and actions (Beetham, 1993, p. 3).

Legitimate power should be "based on fair principles justified by a high substantive assessment of the quality of those having power, and the exercise of power itself should be consistent with social expectations" (Żyromski, 2012, p. 19). Legitimization can be understood as a regulatory (imposed, semi-imposed) norm that evokes certain behaviours, or as an internalised conviction of society (the governed) that the norm is not only mandatory, but also for some rational or emotional reasons is 'right'. The indicated belief should correspond to the content of common beliefs, it should be consistent with the perception of reality, or correspond to values that people would like to follow (Wesołowski, 2001, p. 557).

To sum up, one can point out to the difficulties in formulating a single definition and the multi-faceted aspects of legitimization. Based on the literature review, it can be concluded that the legitimization of power means the acceptance of its activities supported by properly prepared social communication, attitude teaching processes, and the values enabling legitimization. J. Habermas acknowledged that the authorities only need to convince the majority of citizens of their legitimacy, regardless of their moral values and intentions (Sokól, 1997, pp. 18-19). In turn, R. Lane indicates that the award of legitimacy to those in power is possible if the procedures used and the result of actions ended with a positive moral assessment (Kosturbiec, 2001, p. 4). In the case of the pension system, it seems necessary that a public belief exists that the system works according to specific procedures, and the result of the system's activities will bring an appropriate effect (the system will be effective and ensure the payment of pension benefits in the future).

Two orientations of legitimation are distinguished in literature, i.e. strategic (internal) and institutional (external) (Łada and Kozarkiewicz, 2013, p. 167). Internal orientation is connected with undertaking various activities as a result of which the system or a given organisation is to maintain or gain social support and acceptance for its activities, whereas external orientation focuses on the external conditions of the decisions taken. It is assumed that the decisions connected with the functioning of the system or entity are conditioned by external factors, its structure, applicable cultural norms, and the system of values and beliefs (Jastrzębowski, 2014, p. 5). In particular, for the pension system, the shaping of the institutional orientation of legitimization is of importance.

Legitimization is a term presented at various levels. Based on the literature, it is possible to indicate several areas of legitimization analysis, i.e.:

- legitimacy as a claim towards power (system),

- legitimacy as an acceptance of claims towards power (system; belief in legitimization), 
- legitimacy as a justification for those in power, for their special position and privileged access to special values, rights, and privileges,

- legitimacy as a promise that a given system will contribute to fulfilling the needs of different social groups.

Each of the indicated levels is justified when analysing the pension system from the point of view of the legitimacy of its activities. Regardless of the possible approaches to the problem, it should be stated that legitimization is the recognition by subordinate groups of the existing relations of dependence (power) as worthy of being acceptable. This should lead to recognising that the decisions and actions of the ruling groups are worthy of obedience or support, and the system and its institutions are worthy of trust and faith in achieving certain results. Acceptance seems to be an essential element for building a legitimate pension system. However, it is important to note that acceptance implies voluntariness and awareness, due to the fact that it should result from knowledge and evaluation of the operation of a given system. Coercion and unawareness exclude acceptance that is actually just obedience to a given system or authority. It seems important to shape legitimization supported by social acceptance. Acceptance should indicate the conditions necessary for assuming and exercising authority or the functioning of the system. The problem of acceptance may be considered in terms of its effectiveness (Chybalski, 2012, p. 60). ${ }^{1}$

According to S.M. Lipset, one can point out four possible variants of the relationship between legitimacy and effectiveness (see the figure below). First, a high level of legitimacy provides the "extended support reserve," which in the situation of a decrease in the system's effectiveness in meeting social needs, provides stability to it (variant a). The system's effectiveness in terms of achieved goals can be "bought" in a situation of system stability in exchange for the absence of legitimacy (variant d). High level of legitimacy, with low efficiency - variant a, creates variant $\mathrm{c}$ after some time, which indicates system instability. Otherwise, a high assessment of the effectiveness of the system's operations, despite the low legitimization threshold, should lead to variant $b$ with the passing of time.

\begin{tabular}{|c|c|c|}
\hline & \multicolumn{2}{|c|}{ Effectiveness } \\
\hline & Low & High \\
\hline High & $\begin{array}{l}\text { Stability } \\
\text { (a) }\end{array}$ & $\begin{array}{l}\text { Stability } \\
\text { (b) }\end{array}$ \\
\hline ". & $\begin{array}{l}\text { Instability } \\
\text { (c) }\end{array}$ & $\begin{array}{l}\text { Stability } \\
\text { (d) }\end{array}$ \\
\hline
\end{tabular}

Fig. 1. Relationship between system efficiency (effectiveness) and legitimacy Source: (Sokół, 1996, p. 236).

\footnotetext{
${ }^{1}$ Effectiveness is understood as a logical relationship between the effect achieved and the goal assumed.
} 
In the case of the pension system, the best situation would be if it were effective and efficient along with high legitimization (variant $b$ ). Such a system seems to be the most stable, supported by society's acceptance having approval for the decisions taken by those managing the system. A lack of legitimization may lead to civil disobedience, i.e. a situation in which, in the name of beliefs about the injustice and inadequacy of the solutions introduced, individuals decide to object through a deliberate and intentional violation of the law, with readiness to submit to punishment resulting from it (Sokół, 1997; Thoreau, 1970, pp. 280-281).

Future old-age pensioners who do not believe in the legitimacy of the system will consciously avoid participation in the system (this particularly applies to voluntary forms of participation in the system), even if they are aware of the lack of payment of certain pension benefits in the future. The loss of legitimization may also occur as a result of events unfavourable for the system revealing a lack of compliance of activities with social expectations. The social perception of the operation of the pension system and its institutions is important, and not its actual functioning. It is possible to suggest two groups of actions here. The first group will be aimed at eliminating the legitimization gap and demonstrating that the pension system meets social expectations as regards the implementation of this system's basic tasks. The second group of tools is directed solely at improving the efficiency (effectiveness) of the system. In this approach it is only about demonstrating how the system works. However, attention should be paid to the possibility of the occurrence of the so-called 'stratification' (Boxenbaum and Jonsson, 2008), i.e. a situation where social pressure conflicts with the beliefs of those in power about what is effective for the system, or when different groups of stakeholders (future old-age pensioners, pensioner entities) present conflicting expectations. Under such conditions it seems necessary to constantly build the legitimization of the pension system and indicate the importance of legitimization against the background of the Polish conditions of the pension system's functioning.

\section{The Polish pension system and conditions of building legitimization}

When considering the conditions for building the legitimacy of the Polish pension system, it is advisable to analyse and evaluate its levels in the context of the whole system's functioning. This assessment is extremely difficult because the multitude of definitions of legitimization and the variety of factors that influence it, in principle, make it impossible to present an unequivocal standpoint in this aspect. Therefore, it is also difficult to assess the level of legitimization of the Polish pension system, which is also influenced by the limited literature in this area. Nonetheless, it is worth considering this subject matter as in the times of a demographic crisis and the permanently increasing average life of societies, issues related to the pension system seem to gain in importance. 
In an attempt to assess the legitimization of the pension system in Poland, a decision was made to analyse individual levels of legitimation from the point of view of the system's functioning, which are presented in more detail in the above sub-section. Treating legitimization as a claim towards the authority/system, reference can be made to the fact that citizens paying insurance premiums to the pension fund, after meeting certain conditions (e.g. having an appropriate retirement and disability pension period, reaching retirement age, etc.), after ending professional activity are entitled to receive benefits of a claim nature, which in a simplified manner means that they are entitled to apply for payment of benefits in a certain amount before a court. Second, the Constitution of the Republic of Poland (The Constitution of the Republic of Poland, 1997) and other legal acts, including the Act on the social insurance system (The Act of 13 October 1998 on social security system; The Act of 17 December 1998 on pensions and disability pensions from the Social Security Fund; The Act of 28 August 1997 on the organization and functioning of pension funds), guarantee that the disability pension body will comply with the legal provisions and provide supervision over the whole system's functioning. Third, the legislative and executive authorities, selected in democratic elections, are in a privileged position and they adopt these legal acts. Citizens indirectly influence the decisions made, casting votes for specific candidates or political groups in subsequent general elections. Particularly noteworthy is the last legitimization level, namely 'legitimacy' as a promise that a given system will contribute to fulfilling the needs of various social groups. From the point of view of the functioning of the state and its citizens, it is extremely important for the pension system to be acceptable and for subsequent generations to believe in the promises made by the authorities. To make this possible, it is necessary to make the system independent of political disputes and stabilised. Citizens' certainty that the savings accumulated for a pension during the productive period will meet specific needs, protect individuals in economic and social terms, minimize the risk of privation in old age and will have a direct impact on the amount of future benefits, may lead to increased public acceptance of the pension system (Czapiński, Panek, 2015, p. 35). ${ }^{2}$ Securing the future, in a situation of limited professional activity, constitutes one of the basic human needs. Therefore, it is necessary to strive for a situation in which citizens are aware of the principles of the system's functioning and ascertain that today's savings will translate into the amount of their subsequent benefits. All activities that interfere with the accumulated funds and implemented changes in the system's functioning cause its destabilisation (see: Gadomski, 2017) and lowering of the level of legitimization.

In Poland, modifications to the pension system, which already began after World War II, in general have continued to the present day. The new system has been

2 It appears from the conducted "Social diagnosis" that in 2015, 42\% of the respondents showed lack of trust towards the Social Insurance Institution (ZUS) and in 2013 it was as much as $45 \%$. 
functioning in Poland since 1 January 1999. During those two decades, however, it has undergone many extensive modifications, which have affected the level of the citizens' acceptance of its functioning. In 1999 the whole system structure changed. Financial resources, which had so far come from one premium, were divided and, in specified interest rates in relation to the average salary, were redirected to four main funds - pension, disability pension, sickness, and accident. The creation of three pillars was an important element of the reform. The first pillar, of a pay-as-you-go nature since the beginning of its creation, has been compulsory. Benefits paid out of it are financed mainly from current premiums and from the budget and managed by the Social Insurance Institution (ZUS). Joining the second pillar until 2014 was also mandatory, but only for people who were born after 1969. In the period 2018-2020, this pillar, and in particular Open Pension Funds (OFE), began to undergo gradual phasing out, which in effect is to lead to the liquidation of the existing funds in 2020 (see: Szczudlińska-Kanoś, Marzec, 2018a; 2018b).

In Poland, since 1999, apart from the first pillar (ZUS) and the already phasing out Open Pension Funds OFE (second pillar) and the new Employee Capital Plans (PPK), there is also a third, voluntary capital pillar performing the function of an optional source of retirement benefits. These are: Employee Pension Schemes (PPE), Individual Retirement Accounts (IKE), and Individual Pension Security Accounts (IKZE) (see: Sektor funduszy emerytalnych w Polsce, 2016). Despite the efforts of subsequent governments and incentives created (e.g. no need to pay tax on profits after reaching a certain age in the case of IKE, and in the case of IKZE - the possibility of deducting a certain amount for income in the annual tax statements), the number of people making use of these instruments is very low. According to the data of the Polish Financial Supervision Authority, at the end of 2018 IKE covered 995.6 thousand people, but the number of active accounts to which payments were made was only 336,000 (figures for the IKE market for 2018). IKZE covered 730.4 thousand people, of which only 229.5 thousand accounts were funded by payments of the savers ( figures for the IKZE market for 2018). It should be highlighted here that both in the case of IKE and IKZE, after making appropriate tax payments, one can withdraw the funds before reaching retirement age. Other rules will apply to "IKE after OFE". These funds are to be marked and cannot be withdrawn earlier.

Apart from the decision to liquidate the OFE, in 2019 regulations regarding Employee Capital Plans (PPK) were implemented, which will somewhat fill the gap and replace the existing funds collected under the second pillar. The PPK are designed to build a universal system in which the accumulated funds are private, accumulated on individual accounts and inherited. Participation in the system is obligatory for employers, but depending on the size of the employer, it will be introduced progressively. The accounts of PPK participants are funded from three sources: from the employee, from the employer, and from the state budget - the Labour Fund. 
In connection with the fact that PPK accounts are of a private nature, the participants may withdraw funds from them at any time. It is also worth mentioning that, in accordance with the regulations, the premium paid by the employing entity constitutes the employee's income subject to PIT taxation. However, PPK participant's contributions from own resources and public funds are taxation exempt. Due to the above, apart from the higher tax payable by the employee, the employer's contribution is included in the income criterion, among others, in the case of family benefits or from the Alimony Fund.

The reluctance to save voluntarily for retirement is proven by the fact that people who are not in an employment relationship and can pay pension and disability pension premiums ("Czy warto dobrowolnie płacić na ZUS"), ${ }^{3}$ or people who are not subject to social insurance from the subsequent employment relationship, but only voluntarily, usually do not pay pension and disability pension premiums, most probably realising that they should partly determine the future benefits. Most likely such a decision for a significant number of people is influenced by insufficient financial resources, other consumption needs, but also a lack of faith in the profitability (sense) of paying additional premiums. This situation usually occurs in cases of having a full-time employment contract and mandate contracts, or running a business.

The lack of the system's stabilization was affected not only by modifications in the individual pillars, but also by changes in regulations. For example, in January 2013 the increase and equalisation of the retirement age for women and men commenced.

The level of legitimization defined as the promise to meet social needs from the point of view of the pension system is also adversely impacted by economic and demographic analyses related to the effects of the omnipresent demographic crisis. It is predicted that the rising percentage of elderly people, the low number of births, an indisputably positive phenomenon such as the ongoing increase in life expectancy and a decrease in employment among the elderly can have a very negative effect on the amount of benefits (Czapiński, Góra, 2016) ${ }^{4}$ and the replacement rate over the next few years. Based on the report of the Organization for Economic Cooperation and Development (OECD), in 2017 in Poland the replacement rate was only 38.6\% and this was one of the worst results among the countries which had been surveyed. The average replacement rate in OECD countries was 63\% (Pensions at a Glance, 2017). According to the forecasts of the European Commission, in 2070 the replacement rate in Poland will drop to 23\% (The 2018 Ageing Report).

${ }^{3}$ In 2016, 8 thousand people voluntarily paid pension and disability pension premiums and 17.6 thousand for voluntary health insurance "Czy warto dobrowolnie płacić na ZUS".

${ }^{4}$ It appears from the research presented in the report "Retirement awareness of Poles" that as many as $67.2 \%$ of people with higher education and $60.2 \%$ with secondary education are concerned that the failure of the pension system will lead to a reduction in pensions and insolvency of the Social Insurance Institution. Reductions in pensions are a concern for $40.2 \%$ and $39.3 \%$, respectively. 


\section{Conclusion}

Assessing the legitimacy of the pension system is a very difficult task. As the analysis shows, in Poland the problem may be in fulfilling the promise of meeting the social needs of citizens once they have finished their professional activity. Subsequent decisions, political disputes, and changes implemented by the authorities destabilise the pension system and negatively affect the level of credibility of the system's functioning. The pension system, in particular its operational principles, should guarantee the implementation of the basic tasks, e.g. ensuring system security, the payability of specific benefits, etc. The reforms introduced translate into a reluctance to save in the institutions created to accumulate capital that can be used after ending professional activity. This can significantly influence the limitation of the pension system's effectiveness - providing adequate capital for people after ending their professional work. Both full-time employees and persons conducting non-agricultural activities may avoid voluntary saving for their retirement (voluntarily being subject to social insurance under certain conditions - among others payment of other contributions, in the amount of minimum remuneration for work), or saving in accordance with additional and non-mandatory forms existing under the so-called the third pillar (i.e. Employee Pension Schemes (PPE) functioning since the introduction of the reform in 1998; Individual Retirement Accounts (IKE) created in 2004; Individual Pension Security Accounts (IKZE) established in 2011, or the new Employee Capital Plans (PPK) existing since 2019).

It should be noted that the way in which the pension system works may lead to the system being perceived as irresponsible towards society and not guaranteeing the fulfilment of the social needs of people after ending their professional activity. The Polish pension system does not create the conditions for building legitimization as a system responsible towards society. The operating pension institutions, particularly the uncertainty marking their operation, do not create conditions for building social trust in the "rightness" of the pension system supported by social acceptance. Individual factors associated with saving money for the future are influenced by many factors, including political, economic, demographic, psychological, and cultural. The propensity to accumulate savings is largely determined by the range of incentives to use various forms of accumulating capital after ending professional activity, transparency of the pension system's operation, and the citizens' attitude towards the state system, in particular the assessment of its stability. In addition, the credibility and predictability of the functioning of institutions that are part of the pension system shapes the system's legitimization (Perek-Białas, 2017). In Poland, incentives for saving money in the third pillar are still insufficient. Nowadays, public authorities face a great challenge, which is to explain to the citizens the decision to liquidate OFE and to convince them to participate in PPK. Only a socially acceptable pension system can create a condition for trust in the implementation of its basic tasks and constitute the basis for building a pension system which is characterised 
by social legitimacy. The current way of introducing reforms to the pension system does not create the conditions to build legitimization of the pension system.

The actions of the authorities do not create conditions for identifying themselves with institutions and retirement procedures. Future old-age pensioners, due to never-ending reforms and the lack of clear rules of the pension system's operation, may have a problem with recognising and perceiving the system as beneficial for them, i.e. one that will ensure the adequate payment of benefits or accumulated capital needed after they end their professional activity. The current pension system does not create grounds for forming an impression that the procedures, institutions, and directions of the retirement policy are responsible towards society as regards the implementation of the retirement policy.

To further investigate the problem of legitimation in relation to the pension system, it seems necessary to conduct detailed research. The article presents the issue of legitimacy, however, the authors, being aware of the complexity of the problem, have taken the first steps towards analysing the issue. Their analyses confirmed the need for research on legitimacy in three dimensions, i.e. as the adjustment of the dimensions of the institution's operating environment, the justification for the operation of a specific institution socially (for the benefit of society) and the assumptions of the system according to norms, values and beliefs.

\section{Bibliography}

Banchoff, T. (1999). National identity and EU legitimacy in France and Germany. In T. Banchoff, M. P. Smith (Eds.), Legitymacy and the European Union. The contested polity. London-New York. Beetham, D. (1993). Legitymizacja władzy. In Elity, demokracja, wybory. Wybór i opracowanie J. Szczupaczyński. Warszawa: Agencja Scholar.

Biernat, T. (2000). Legitymizacja władzy politycznej. Elementy teorii. Toruń: Wydawnictwo Adam Marszałek.

Boxenbaum, E., and Jonsson, S. (2008). Isomorphism, diffusion and decoupling. In R. Greenwood, Ch. Oliver, R. Suddaby, K. Sahlin (Eds.), The Sage Handbook of Organizational Institutionalism. London: Sage Publishing.

Chłon-Domińczak, A., Góra, M., and Rutecka, J., Konsekwencje zmian w systemie emerytalnym z punktu widzenia osób ubezpieczonych. Retrieved August 23, 2019 from http://uczelnia.sgh.waw.pl/pl/ uczelnia/badania/grupy_badawcze/ppg/Documents/Badania\%20naukowe/Konsekwencje\%20 zmian $\% 20 \mathrm{w} \% 20$ systemie $\% 20$ emerytalnym $\% 20 \mathrm{dla} \% 20$ ubezpieczonych_raport\%20PPE.pdf

Chybalski, F. (2012). Skuteczność i efektywność systemu emerytalnego. Koncepcja analizy i próba pomiaru. Zeszyty Naukowe, (111), Rozprawy Naukowe, (419).

Czapiński, J., and Panek, T. (Eds.). (2015). Diagnoza społeczna 2015. Warunki i jakość życia Polaków, Warszawa. Retrieved from http://www.diagnoza.com

Czapiński, J., and Góra, M. (2016). Świadomość emerytalna Polaków. Raport z badania ilościowego. Warszawa. Retrieved August 24, 2019 from https:/www.efcongress.com/sites/default/files/analizy/raport.pdf

Czy warto dobrowolnie płacić na ZUS. (2016, September 24). Rzeczpospolita. Retrieved August 24, 2019 from https://www.rp.pl/Ubezpieczenia/309249958-Czy-warto-dobrowolnie-placic-na-ZUS. html 
Dahl, R. A. (1963). Modern political analysis. Englewood Cliffs, N.J.: Prentice-Hall.

Dziennik.pl (2014, August 18). OFE wybrało ponad 2,5 mln Polaków. Ostateczne dane. Retrieved from https://gospodarka.dziennik.pl/emerytury-i-ofe/artykuly/467317,ofe-wybralo-ponad-2-5-mln-polakow-ostateczne-dane-zus.html,24.08.2019

eKAI. (n. d.). Prezes ZUS: zaufanie do systemu emerytalnego wynika z jego stabilności. Retrieved August 21, 2019 from https://ekai.pl/prezes-zus-zaufanie-do-systemu-emerytalnego-wynika -z-jego-stabilnosci/

Fandrejewska, A. (2016, September 24). Czy warto dobrowolnie płacić na ZUS. Retrived 2019, August 24 from https://www.rp.pl/Ubezpieczenia/309249958-Czy-warto-dobrowolnie-placic-na-ZUS.html, dostęp: 24.08.2019.

Gadomski, W. (2017, September 15). Emerytury wymagają stabilności. A mamy chaos, który zmniejsza zaufanie obywateli do systemu emerytalnego i zachęca do emigracji. Gazeta Wyborcza. Retrieved August 24, 2019 from http://wyborcza.pl/7,155290,22378544,emerytury-wymagaja-stabilnosci-a-mamy-chaos-ktory-zmniejsza.html

Gubernat, E. (2009). Stabilny system emerytalny w świetle reformy emerytalnej z 1999 roku. In F. Chybalski, I. Staniec (Eds.), 10 lat reformy emerytalnej w Polsce. Efekty, szanse, perspektywy i zagrożenia. Monografie Politechniki Łódzkiej. Łódź.

Jastrzębowski, A. (2014). Teoria legitymizacji a funkcje rachunkowości. Studia Oeconomica Posnaniensia, 2, 4(265).

Kasper Ł., and Łączny R. (2019, March 26). Prezes ZUS: zaufanie do systemu emerytalnego wynika z jego stabilności. Retrived August 212019 from https://ekai.pl/prezes-zus-zaufanie-do-systemu-emerytalnego-wynika-z-jego-stabilnosci/

Komisja Nadzoru Finansowego [KNF]. (2016). Sektor funduszy emerytalnych w Polsce - ewolucja, ksztalt, perspektywy. Warszawa: Urząd Komisji Nadzoru Finansowego. Retrieved August 24, 2019 from https://www.knf.gov.pl/knf/pl/komponenty/img/knf_157592_Sektor_funduszy_emerytalnych_w_Polsce_2016_47307_56352.pdf

Komisja Nadzoru Finansowego [KNF]. (n. d.). Information in figures about the IKE market for 2018. Retrieved August 2, 2019 from https://www.knf.gov.pl/?articleId=64783\&p_id=18

Kosturbiec, J. (2001). Istota prawnej legitymizacja władzy. Studenckie Zeszyty Naukowe, (4/5), 8-23.

Kubin, T. (2014). Legitymizacja systemu politycznego Unii Europejskiej. Prace Naukowe Uniwersytetu Ślaskiego w Katowicach, (3222).

Lipset, S. M. (1960). Political Man. The Social Bases of Politics. New York. Retrieved from https:// archive.org/details/politicalmansoci00inlips/page/n7/mode/2up

Łada, M., and Kozarkiewicz, A. (2013). Teoria legitymizacji w badaniach z zakresu rachunkowości. Zeszyty Teoretyczne Rachunkowości, 71(127).

Orenstein, M., (2013). Prywatyzacja emerytur. Transnarodowa kampania na rzecz reformy zabezpieczenia społecznego. Warszawa: PTE.

Pensions at a Glance 2017, OECD and G20 indicators. Retrieved August 23, 2019 from https://www. oecd-ilibrary.org/docserver/pension_glance-2017-en.pdf?expires $=1566566239 \& \mathrm{id}=\mathrm{id} \&$ accname =guest\&checksum $=75$ ACA56F9ED10DC00813FB33D8E54800

Perek-Białas, J. (2017). Zaufanie obywateli do systemu emerytalnego a skłonność do oszczędzania na starość. Ubezpieczenia Społeczne, (2), 84-88. Retrieved August 23, 2019 from https://www.zus.pl/ documents/10182/1083093/Ubezp.+Spo\%C5\%82eczne+nr+2_2017_J.+Perek-Bia\%C5\%82as. pdf/0cc8afa3-c511-43ea-ad2f-42cf3b8cc7d4

Stownik Języka Polskiego PWN. (n. d.). Retrieved August 20, 2019 from https://sjp.pwn.pl/slowniki/ legitymizacja.html

Sokół, W. (1995). Stabilizacja, legitymacja i legitymizacja ładu społecznego - problemy teoretyczne i aksjologiczne. In M. Chmaj, Społeczeństwo, państwo, władza, Lublin: Lubelskie Towarzystwo Naukowe. 
Sokół, W. (1996). Legitymizacja systemu politycznego - jako kategoria analityczna. Annales Universitatis Marie Curie-Skłodowska Lublin - Polonia. Vo. II/III. Sectio K.

Sokół, W. (1997). Legitymizacja systemów politycznych. Lublin: Wyd. UMCS.

Szczudlińska-Kanoś, A., and Marzec, M. (2018a). Zaufanie jako wartość w polityce społecznej wobec osób starszych. Kraków: Wyd. Instytutu Spraw Publicznych Uniwersytetu Jagiellońskiego.

Szczudlińska-Kanoś, A., and Marzec, M. (2018b). The levels of trust in the pension system: a Polish perspective. Kwartalnik Kolegium Ekonomiczno-Społecznego. Studia i Prace, (4).

The 2018 Ageing Report Economic \& Budgetary Projections for the 28 EU Member States (2016-2070) INSTITUTIONAL PAPER 079, MAY 2018. Retrieved 23 August, 2019 from http://englishbulletin.adapt.it/wp-content/uploads/2018/07/ip079_en.pdf

The Act of 13 October, 1998 on social security system (Journal of Acts of 1998 no. 137, item 887 as amended and among others)

The Act of 17 December, 1998 r. on pensions and disability pensions from the Social Security Fund (Journal of Acts of 1998 no. 162, item 1118 as amended)

The Act of 28 August, 1997 on organization and functioning of pension funds (Journal of Laws 1997 no. 139 , item 934 as amended)

The Constitution of the Republic of Poland of 2 April, 1997 (Journal of Acts 1997 no. 78 item 483, as amended).

Thoreau, H. W. (Ed.). (1970). Civil Disobedience. New Jork.

Wara-Wąsowska, E., Nieufność do PPK nie wzięta się znikad. I nie chodzi tylko o OFE, ale o całokształt działań kolejnych ekip rzadzacych. Retrieved August 23, 2019 from https://bezprawnik.pl/ polacy-nie-ufaja-ppk/

Wesołowski, W. (2001). Legitymizacja jako potoczna filozofia władzy. Studia Socjologiczne, 2(161).

Winczorek, P. (1985). Legitymizacja władzy politycznej. Państwo i Prawo, 11-12(85).

Żyromski, M. (2012). Legitymacja czy legitymizacja władzy. Doświadczenia państw Europy Środkowej. Środkowoeuropejskie Studia Polityczne, (3), 7-26. Retrieved from http://hdl.handle.net/ $10593 / 8046$ 